\title{
FORAGING AND MOBILITY IN THREE SPECIES OF ACICULATA (ANNELIDA: POLYCHAETA)
}

\author{
PARDO, E. V. and AMARAL, A. C. Z. \\ Departamento de Zoologia, Instituto de Biologia, Universidade Estadual de Campinas, \\ C. P. 6109, CEP 13083-970, Campinas, São Paulo, Brazil \\ Correspondence to: Erica Veronica Pardo, Departamento de Zoologia, Instituto de Biologia, \\ Universidade Estadual de Campinas, C. P. 6109, CEP 13083-970, \\ Campinas, São Paulo, Brazil, e-mail: evpardo@sigmanet.com.br \\ Received February 3, 2005 - Accepted August 22, 2005 - Distributed November 1, 2006
}

(With 1 figure)

\begin{abstract}
Aspects of feeding, such as food capture and ingestion, as well as mobility of the polychaetes Eurythoe complanata, Marphysa formosa and Diopatra aciculata, from São Sebastião Channel (São Sebastião, state of São Paulo) were observed in laboratory conditions. Eurythoe complanata, a carnivorous species, fed exclusively on pieces of fish with the aid of strong muscular retractable lips, and detected the presence of food by chemical stimuli. Diopatra aciculata, an omnivorous species, captured and ingested different kinds of food with the aid of its jaws, generating a flow of water through its tube by which it detects the presence of food and oxygenates its gills. Marphysa formosa also used its jaws to bite and lacerate food. These species showed greater or lesser degrees of intolerance to light.
\end{abstract}

Keywords: foraging, mobility, Aciculata, Polychaeta, Annelida.

\section{RESUMO}

\section{Forrageamento e mobilidade em Polychaeta}

Alguns aspectos da atividade alimentar, tais como a captura e ingestão de alimento, bem como a mobilidade dos poliquetas Eurythoe complanata, Marphysa formosa e Diopatra aciculata, procedentes do Canal de São Sebastião (São Sebastião, SP), foram observados em laboratório. Eurythoe complanata, carnívora, alimentou-se apenas de pedaços de peixe, utilizando os lábios retráteis fortemente musculares e detectando a presença do alimento através de estímulos químicos. Diopatra aciculata, onívora, capturou (com o auxílio das maxilas) e ingeriu os diferentes tipos de alimentos oferecidos, promovendo um fluxo de água para dentro do tubo, por meio do qual o animal detecta a presença de alimento e oxigena as brânquias. Marphysa formosa também utilizou as maxilas para morder ou rasgar o alimento. Durante as observações, foi constatado que estes poliquetas, em maior ou menor grau, apresentam intolerância à luminosidade.

Palavras-chave: forrageamento, mobilidade, Aciculata, Polychaeta, Annelida.

\section{INTRODUCTION}

Polychaetes (class Polychaeta, phylum Annelida) are among the most morphologically diverse marine invertebrates, which is probably related to their occupation of a wide variety of marine habitats. This diversity in morphology and use of habitats has led to a corresponding diversification in feeding mechanisms (Amaral \&
Nonato, 1996). Polychaetes have been well studied taxonomically (Fauvel, 1923, 1927; Hartman, 1959a, 1959b, 1963a, 1963b, 1965, 1968, 1969; Day, 1967a, 1967b; Uebelacker \& Johnson, 1984; Blake et al., 1995, 1996, 1997; Amaral \& Nonato, 1996, among others), whereas ecologically they are still poorly understood (feeding behaviors: Brenchley, 1976; Shaffer, 1979; Brenchley \& Tidball, 1980; Mettam, 1980; Dauer et al., 1981; 
Mattson, 1981; Bell \& Coen, 1982; Dauer, 1983, 1985, 1991, 1997; Pleijel, 1983; Bell, 1985; Peckol \& Baxter, 1986; Vreeland \& Lasker, 1989; Dauer \& Ewing, 1991; life history: Mayer et al., 1995; Scaps, 1995; Dill \& Fraser, 1997). Some of their adaptations are well known, such as in the family Sabellidae whose members use their tentacular crown for filter-feeding, and the family Spionidae whose members capture food particles by keeping their palps suspended in the water. Members of the families Terebellidae and Cirratulidae are detritivores that forage on the surface of sediment.

Amphinomid polychaetes are normally found in tropical and subtropical waters. Many species in this family are cryptic, especially in the intertidal zone and shallow waters, where a variety of hiding places are available, such as beneath stones and in corals (Day, 1967a; Blake et al., 1995). Most amphinomids are carnivorous, feeding on sponges, anemones, hydroids and ascidians (Day, 1967a; Vreeland \& Lasker, 1989); whereas others, such as Eurythoe, are omnivorous and scavengers (Blake et al., 1995). Eurythoe complanata and other members of this family are known as fire-worms because they bear calcareous, vitreous bristles or hairs containing neurotoxins that can cause great discomfort when they come into contact with the skin (Blake et al., 1995; Amaral \& Nonato, 1996). This nocturnal or crepuscular species is abundant in the intertidal zone and under rocks on sandy beaches off the northern coast of the state of São Paulo (Blake et al., 1995; Pardo, 1995).

The family Eunicidae is widely distributed, occurring from the intertidal zone to deeper waters (Blake et al., 1995). The species of this family occupy diverse habitats, and their foraging strategies vary greatly (Day, 1967a). Eunicids are active and typically burrow in sand and mud. Most of them are carnivores; some species of Marphysa are herbivores and omnivores (Fauchald \& Jumars, 1979; Pettibone, 1982; Gathof, 1984).

Members of the family Onuphidae may be found in any type of habitat and at any depth. They are tubicolous, although not necessarily sessile. They build a variety of types of tubes that are longer than their bodies (Blake et al., 1995), and they capture a variety of prey, including the epifauna associated with their tubes (Brenchley, 1976; Brechley \& Tidball, 1980; Bell, 1985; Peckol \& Baxter, 1986). Individuals of Diopatra aciculata, although supposedly herbivorous, have been found with algae, sponges, bryozoans, crustaceans and detritus in their guts, suggesting an omnivorous habit (1931, Younge 1954 apud Fauchald \& Jumars, 1979). This species builds elaborate tubes composed of shells, pieces of algae, detritus or any object available in the sediments. The anterior end of the tube extends above the surface of the sediment. It is usually curved, possibly for protection from predators.

Feeding and foraging behaviors will be discussed in this chapter. We focus on the feeding of three species of polychaetes, which were studied in the laboratory: Eurythoe complanata (Amphinomidae), Marphysa formosa (Eunicidae) and Diopatra aciculata (Onuphidae). These species are common and frequent in certain sandy beaches along the São Sebastião Channel and at Caraguatatuba (Pardo, 2000; Steiner \& Amaral, 2000).

\section{METHODS}

Specimens of Eurythoe complanata, Diopatra aciculata and Marphysa formosa were obtained from São Francisco Beach $\left(23^{\circ} 44.8^{\prime} \mathrm{S}\right.$ and $45^{\circ}$ $24.7^{\prime} \mathrm{W}$ ) in São Sebastião (SP) on the continental side of the São Sebastião Channel. This beach is very shallowly sloped in the intertidal zone, and the substrate comprises a mixture of sand and stones of different sizes (Denadai \& Amaral, 1999). The annual mean water temperature is about $24{ }^{\circ} \mathrm{C}$.

Samples were collected during low tide in the intertidal zone. Marphysa formosa $(\sim 35 \mathrm{~mm}$ long, $\sim 2 \mathrm{~mm}$ in diameter) and Diopatra aciculata $(\sim 53 \mathrm{~mm} \mathrm{x} \sim 4 \mathrm{~mm})$ were collected in sediments up to $30 \mathrm{~cm}$ deep. Eurythoe complanata $(\sim 45 \mathrm{~mm} \mathrm{x}$ $\sim 8 \mathrm{~mm}$ ) was collected beneath stones. Individuals of Marphysa formosa were collected throughout the study (January - August 1998), because they did not survive in captivity for more than one month. Eurythoe complanata and Diopatra aciculata were collected only once, because they survived in the laboratory through the entire study period. All the individuals were placed in transparent plastic containers covered by a nylon screen $(0.3 \mathrm{~mm}$ mesh), which allowed circulation of water and prevented escapes. Seven aquaria were used: three $400 \mathrm{~mL}$ aquaria, each with three individuals of Eurythoe complanata; one $200 \mathrm{~mL}$ aquarium, 
with one individual of Diopatra aciculata; and three $200 \mathrm{~mL}$ aquaria, each with one individual of Marphysa formosa. During the observation periods, the aquaria were placed in a plastic box (length $45 \mathrm{~cm}$, width $28 \mathrm{~cm}$, height $16 \mathrm{~cm}$ ) equipped with a sea-water flow system, at the laboratory of the Marine Biology Center of the University of São Paulo (CEBIMar - USP), thereby maintaining suitable laboratory conditions for the animals. All observations were done at room temperature ( $\mathrm{min}$. $28{ }^{\circ} \mathrm{C}-\max .33^{\circ} \mathrm{C}$ ).

The observations began as the animals were seen to be moving around normally, and were made by means of a binocular microscope. Buried animals were not shielded from the lighting. Observations were also made on worms in Petri dishes with a small amount of sediment, for which illumination was provided by a lamp shielded by a red cellophane filter (the animals were less disturbed by red light). All the observations of Eurythoe complanata were made with filtered light. Observations of Diopatra aciculara did not require a filter, because the low intensity of light was enough to study the animals. Sometimes, a hand lens was used for observations.

Observation periods varied by species: $E$. complanata - 21 h, M. formosa - 11 h, D. aciculara$6 \mathrm{~h}$. The observation conditions varied by species as well. Marphysa formosa received a small stone covered with algae, sand and small animals, such as crustaceans. Diopatra aciculata and Eurythoe complanata received pieces of algae (Ulva sp.), small crustaceans and polychaetes, pieces of coral, sponges and fish. To test whether polychaetes detected the odor of food, liquid from a macerated fish preparation was released into the aquarium.

\section{RESULTS}

\section{Eurythoe complanata (Pallas, 1766)}

Eurythoe complanata showed a typical feeding behavior. The only food taken was fish, in small pieces $(2 \mathrm{~mm})$. The time between detection and capture of the food was approximately $5 \mathrm{~min}$, when the animal placed its mouth over the food and ingested the entire piece. During this process, the anterior margin of the strongly muscled pharynx was partially exposed, forming a lip 4-5 times longer than its normal size, which functioned as a suction pump. The exposed inner wall of the pharynx was reddish, with lighter stripes that seemed to act as grooves, driving the food into the gut. After ingesting the fish, the animals returned beneath the rocks, where they remained still, associated in groups until the next feeding session.

When the fish solution (macerated fish with water) was placed in the aquaria, the worms responded almost immediately, turning the ventral side of their bodies upwards. With approximately $1 / 3$ of the body erect in the water column, the animals opened and closed their mouths, everting the pharynx. Once, two individuals moved toward the same piece of fish, then one worm pushed the other with lateral movements of its body and ingested the fish.

During this study some individuals spontaneously broke into fragments. This fragmentation was followed by rapid regeneration. Also, under strong illumination the animals seemed to be uncomfortable, moving rapidly on the substrate, apparently searching for refuge. When they were touched, the polychaetes rapidly rolled up, exposing and erecting their vitreous bristles, some of which were apparently released from the body.

\section{Marphysa formosa Steiner \& Amaral, 2000}

Marphysa formosa was observed while feeding positioned on small stones (covered with algae and its associated fauna) in the aquaria, on sediments, or in Petri dishes. Once positioned on the algae, the animals seemed to graze on them, everting the pharynx armed with strong mandibles and maxillae and cutting the algae. Capture or ingestion of fauna associated with algae was never observed. After feeding, the animals left the stones bare, without algae.

The worms moved between the algae and the stones, sheltering themselves within fragile tubes of sand and mucus. They did not feed while they were building their tubes. While they were inside their tubes, the animals remained still, buried in the sediments.

In the Petri dish, under ambient light, Marphysa formosa moved rapidly over the surface of the substrate, apparently searching for shelter. One individual was observed (under red light) in a Petri dish that contained so little sediment that the animal could not bury itself. The worm began to cover itself with sand and secreted mucus. First it covered its anterior end, then it turned in the tube 
and covered its posterior region, gradually gathering more sand and building a tube. Another individual observed in a Petri dish with a similar amount of sediment built a gallery of tubes. The animal gathered or stuck the sand on the ventral part of its prostomium, and then moved the sand backwards towards the dorsal part of its body, using the first parapodia and setae. It frequently turned in the tube. When this specimen was observed again in the Petri dish with little sediment and shaded from the light, it began to construct the tube (as previously described), moving along the dish, backing up through about one-third the length of the tube and beginning another one, backing up again through one-third of the tube and forming a third tube and then a fourth, and then turned its body (not backing up) and began again, thus forming tunnels, or rather galleries, on the sediment, as shown in Fig. 1.

\section{Diopatra aciculata Knox \& Cameron, 1971}

One individual of Diopatra aciculata was observed in the aquarium 20 days after it was collected. During this time it built a tube of sediment particles and pieces of vegetation. Diopatra aciculata remained within the tube, only extending the tips of its antennae from the tube. This worm ate all types of food offered (fish, other live or dead polychaetes, and algae). The animal captured the food rapidly, although it never extended more than about one-third of its body from the tube, and then only briefly. When food was offered, the worm extended part of its body from the tube, touched the food with its antennae, then rapidly captured the food with its maxilla (in the evertible pharynx) and buccal labia. The animal then withdrew into the tube to eat the food. When a live polychaete, Nematonereis hebes, was offered, it was captured and pulled into the tube, from which it immediately escaped.

Cylindrical, rounded, $2 \mathrm{~mm}$ long fecal pellets were noticed near the mouth of the tube. Occasionally, the worm apparently cleaned the interior wall of the tube. Using the smaller antennae and buccal labia, the animal grasped a grain of sand and rubbed it against the interior wall of the tube, twisting its body within the tube, gradually cleaning the entire inner wall.

\section{DISCUSSION}

\section{Eurythoe complanata (Pallas, 1766)}

Eurythoe complanata is carnivorous, eating live as well as dead animals (Kudenov, 1974 in Fauchald \& Jumars, 1979). Amphinomids associated with hard substrates are carnivorous and consume live prey, whereas those living in sediments feed largely on dead animal remains (Fauchald \& Jumars, 1979). These behaviors were confirmed in this study. The exception is the omnivorous Hermodice carunculata, which may select for prey types (Vreeland \& Lasker, 1989), and also has a diverse diet, consuming detritus, plant remains, zooanthids, hydrocorals, hexacorals and octocorals (Martin \& Losada, 1997).

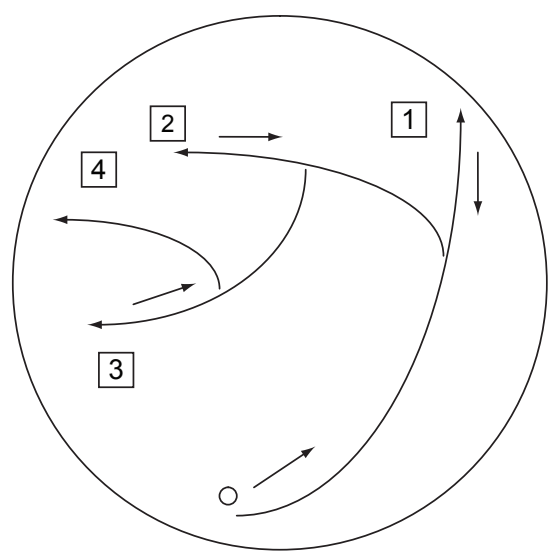

Fig. 1 - Movements of an individual Marphysa formosa in a Petri dish (circle = beginning of movement; lines = tunnels; numbers $=$ stages; arrows $=$ direction of movements). 
The feeding behavior of E. complanata is similar to that of other members of Amphinomidae (Day, 1967a; Fauchald \& Jumars, 1979). The response of these animals to water containing macerated fish demonstrates that they have a chemosensory perception that is associated with prey capture.

Eurythoe complanata normally hides by day (Kudenov, 1974 in Fauchald \& Jumars, 1979), apparently for protection from desiccation (Suadicani \& Moreira, 1988). Here, while desiccation was not a problem, the animals still avoided light. Normal foraging is either crepuscular or nocturnal (Blake et al., 1995). This species defends itself by the use of toxins in the bristles, which are erected when the animals are disturbed (Suadicani et al., 1993).

\section{Marphysa formosa Steiner \& Amaral, 2000}

Marphysa formosa fed only on algae. It also built its fragile sandy tubes among the algae. Species of Marphysa may be herbivorous, carnivorous or omnivorous (Fauchald \& Jumars, 1979). Although filtered light was used in the observations, the light intensity may still have influenced the behavior. Under observation conditions, the animals became more agitated. Also, the small amount of sediment available during the observation periods may have influenced the behavior of the animals, even though they remained buried. Individuals of the aphroditid species Aphrodita aculeata, when unsheltered show no interest in feeding, whereas when they are buried or inside their tubes, they forage and feed normally (Mettam, 1980). Glycera alba did not feed outside of its tube gallery (Ockelmann \& Vahl, 1970). In an aquarium, Pholoe minuta, only captured its prey when both the worm and the prey were buried (Pleijel, 1983). Because the genus Marphysa comprises burrowing species (Day, 1967a), it is possible that the species studied here also feeds while buried.

The movements over the bottom of the Petri dish observed in this study may be related to the way in which the animal moves inside the substrate or constructs its galleries. In this case, the very irregular excavations, which easily crumble when touched, may be the equivalent of a system of galleries cemented with a thin layer of mucus, similar to the figure given by Barnes (1984; p. 540;
Fig. 11-17). In Barnes' system, the animal had complete freedom of movement.

Glycera alba builds complex tube systems. During the construction of these tubes, the worm uses complex parapodial and serpentine movements as well as slow peristaltic and antiperistaltic movements of the body (Ockelmann $\&$ Vahl, 1970). These behaviors seem to be similar to those of the species of Marphysa studied here. Marphysa formosa is apparently an omnivorous species, actively burrowing into the substrate and inhabiting complex galleries of tubes, although it fed only on algae during this study.

\section{Diopatra aciculata Knox \& Cameron, 1971}

Most onuphids are omnivorous and opportunistic animals, feeding on almost any organic material available (Fauchald \& Jumars, 1979). Diopatra aciculata was unable to consume Nematonereis hebes because the latter species was always able to escape. Individuals of Diopatra cuprea, kept without food in the laboratory for six weeks or more, responded to any food stimulus, and this response was continuous (Mangum \& Cox, 1971). In the study of Mangum \& Cox (1971), the acclimation period was at least three days, because after that time the animals started to feed. In the present study, for about a month $D$. aciculata fed only on the organic material available in the aquarium sediments, and responded to all food stimuli.

The longitudinal movements of D. aciculata, while slightly different from those reported by Mangum et al. (1968) and Mangum \& Cox (1971) for $D$. cuprea, are not primarily for oxygenation as these investigators suggested, but rather are sensory (to locate prey). Oxygen consumption is low, and so the irrigation of the tube is much greater than required for respiration alone (Mangum et al., 1968).

The "feeding response" is a behavioral pattern that is initiated by a food stimulus (Magnum \& Cox, 1971). This pattern has three components, each with its characteristic behavior: 1) The rheotactic component is initiated by the contact of the animal with fluids.; 2) The chemotactic component is initiated by chemical stimuli; 3 ) The chemo-mechanotactic component is initiated by simultaneous chemical and mechanical stimuli. Here, Diopatra felt the prey prior to its capture, 
which suggests that it was using the chemomechanotactic component.

The tubes of $D$. aciculata were already in place when observations began, after 20 days in the aquarium. In $D$. cuprea the tubes were probably built within 2 or 3 days (Brenchley, 1976). In Narragansett Bay (Rhode Island, USA), D. cuprea was observed rebuilding its tube through $28 \mathrm{~cm}$ of sedimentation above the substrate in 21 hours at $20^{\circ} \mathrm{C}$ (Myers, 1972). Apparently, tube construction does not occur below $1.8{ }^{\circ} \mathrm{C}$ (Myers, 1972). Diopatra cuprea builds a two-part tube. The first, reinforced part extends above the surface and is normally curved, and various shell fragments, small rocks, algae and other objects are attached to it in mucus layers. The second, unreinforced part is beneath the surface and is composed of only sand and mucus (Myers, 1972; Brenchley, 1976). Tube ornamentation probably serves as camouflage and as an apparatus to capture prey. The ornamentation of the tube of $D$. cuprea may serve as camouflage, because the degree of ornamentation was closely related to the shell fragments available in the sediment; or alternatively as a food capturing apparatus. It may also aid in detecting predators: Brenchley (1976) found in experiments that individuals of Diopatra without ornamentation on their tubes could not distinguish among different kinds of mechanical disturbances applied to them. Also, there is a complex fauna associated with the tube, which may be influenced by the types and sizes of materials that the worm uses to build them (Bell \& Coen, 1982; Bell, 1985).

Diopatra cuprea also fed on the fauna associated with its tubes; these polychaetes may control the density and distribution of this associated fauna (Mangum et al., 1968). The orientation of the tube depends on the population density of the worms, so that a single individual may orient itself to the water current to optimize foraging efficiency. In a group of worms, this kind of orientation is not possible because of interactions among individuals, and in this case, the worm will orient itself in the most efficient way possible (Brenchley \& Tidball, 1980). Diopatra aciculata was observed cleaning the inner wall of its tube, holding a sand grain between its palp and buccal labia. The purpose of this behavior is presumably to remove extraneous particles adhering to the wall (Mangum et al., 1968). Diopatra aciculata is an omnivorous and opportunistic polychaete, adapting its diet to the food available.

Eurythoe complanata, Marphysa formosa and Diopatra aciculata behave as carnivorous, herbivorous and omnivorous species respectively. In the region studied, there is no known physical factor associated with the diet and habits of these worms. It is important to recognize that in natural conditions these animals may have different feeding behaviors. Also, the availability of food in natural conditions will determine the feeding patterns of these animals.

Acknowledgments - We would like to thank E. Soares Marinho, A. Máximo Rosa (UNICAMP) and the CEBIMar technicians, who assisted with the fieldwork. We are particularly grateful to the 'Centro de Biologia Marinha (CEBIMar - USP)' for logistical support. This research was supported by grants from the 'Fundação Coordenação de Aperfeiçoamento de Pessoal de Nível Superior (CAPES)' and from the 'Fundo de Apoio à Pesquisa (FAEP-UNICAMP)'. Dr. James J. Roper translated the text into English. Dra. Janet Reid reviewed the English.

\section{REFERENCES}

AMARAL, A. C. Z. \& NONATO, E. F., 1996, Annelida Polychaeta: características, glossário e chaves para famílias e gêneros da costa brasileira. Campinas, SP: Editora da UNICAMP, 124p.

BARNES, R. D., 1984, Zoologia dos invertebrados. $4^{\text {a }}$ edição. São Paulo: Livraria Roca LTDA, 1179p.

BELL, S. S., 1985, Habitat complexity of the polychaete tubecaps: Influence of the architecture on dynamics of a meioepibenthic assemblages. J. Mar. Res., 43: 647-671.

BELL, S. S. \& COEN, L. D., 1982, Investigations on epibenthic meiofauna. II. Influence of microhabitat and macroalgae on abundance of small invertebrates on Diopatra cuprea (Bosc) (Polychaeta: Onuphidae) tube-caps in Virginia. $J$. Mar. Biol. Ecol., 61: 175-188.

BLAKE, J. A., HILBIG, B. \& SCOTT, P. H., 1995, The Annelida Part 2 -Polychaeta: Phyllodocida (Syllidae and Scale bearing families), Amphinomida and Eunicida. $5^{\circ}$ vol., Serie: Taxonomic Atlas of the Benthic Fauna of the Santa Maria Basin and Western Santa Barbara Channel. Santa Barbara Museum of Natural History, Santa Barbara, California. 378p.

BLAKE, J. A., HILBIG, B. \& SCOTT, P. H., 1996, The Annelida Part 3 - Polychaeta: Orbiniidae to Cossuridae. $6^{\circ}$ vol., Serie: Taxonomic Atlas of the Benthic Fauna of the Santa Maria Basin and the Western Santa Barbara Channel. Santa Barbara Museum of Natural History, Santa Barbara, California. 418p.

BLAKE, J. A., HILBIG, B. \& SCOTT, P. H., 1997, The Annelida Part 1 - Oligochaeta and Polychaeta: Phyllodocida (Phyllodocidae to Paralacydoniiae). $4^{\circ}$ vol., Série: Taxonomic Atlas of the Benthic Fauna of the Santa Maria Basin and the Western Santa Barbara Channel. 
Santa Barbara Museum of Natural History, Santa Barbara, California. 369p.

BRENCHLEY, G. A., 1976, Predator detection and avoidance: ornamentation of the tube-caps of Diopatra cuprea spp. (Polychaeta: Onuphidae). Mar Biol., 38: 179-188.

BRENCHLEY, G. A. \& TIDBALL, J. G., 1980, Tube-caps orientations of Diopatra cuprea (Bosc) (Polychaeta): the compromise between physiology and foraging. Mar. Behav. Physiol., 7: 1-13.

DAUER, D. M., 1983, Functional morphology and feeding behavior of Scolelepis squamata (Poychaeta: Spionidade). Mar. Biol., 77: 279-285.

DAUER, D. M., 1985, Functional morphology and feeding behavior Paraprionospio pinnata (Polychaeta: Spionidae). Mar. Biol., 85: 143-151.

DAUER, D. M., 1991, Functional morphology and feeding behavior of Polydora commensalis (Polychaete: Spionidae). Ophelia Suppl., 5: 607-614.

DAUER, D. M., 1997, Functional morphology and feeding behavior of Marenzelleria viridis (Polychaeta: Spionidae). Bull. Mar. Sci., 60: 512-516.

DAUER, D. M. \& EWING, R. M., 1991, Functional morphology and feeding behavior of Malacoceros indicus (Polychaeta: Spionidae). Bull. Mar. Sci., 48: 395-400.

DAUER, D. M., MAYBURY, C. A. \& EWING, R. M., 1981, Feeding behavior and general ecology of several spionid polychaetes from the Chesapeake Bay. J. Exp. Mar. Biol. Ecol., 54: 21-38.

DAY, J. H., 1967a, Polychaeta of southern Africa. Part 1. Errantia. London, British Mus. (Nat. Hist.), Publ. n. 655, 458p.

DAY, J. H., 1967b, Polychaeta of southern Africa. Part 2. Sedentaria. London, British Mus. (Nat. Hist.), Publ. n. 656, 420p.

DENADAI, M. R. \& AMARAL, A. C. Z., 1999, A comparative study of the intertidal molluscan community in sandy beaches, São Sebastião Channel, São Paulo State, Brazil. Bull. Mar. Sci., 65: 91-103.

DILL, L. M. \& FRASER, A. H. G., 1997, The worm re-turns: hiding behavior of a tube-dwelling marine polychaete, Serpula vermicularis. Behav. Ecol., 8: 186-193.

FAUCHALD, K. \& JUMARS, P. A., 1979, The diet of worms: a study of polychaete feeding guilds. Oceanogr. Mar. Biol. Ann. Rev., 17: 193-284.

FAUVEL, P., 1923, Polychètes Errantes. Faune Fr., 5: 1-488.

FAUVEL, P., 1927, Polychètes Sedentaires. Addenda aux Errantes, Archiannélides, Mysostomaires. Faune Fr, 16: $1-494$.

GATHOF, J. M., 1984, Family Eunicidae Savigny, 1818, pp. 40.1-40.3. In: J. M. Uebelacker, P. J. Johnson (eds.). Taxonomic guild to the polychaetes of the Northern Gulf of Mexico. Mobile, Alabama: Barry A. Vittor \& Associates, $6^{\circ}$ vol., capítulo 40.

HARTMAN, O., 1959a, Catalogue of the Polychaetous Annelids of the World. Pt. I. Occ. Pap. Allan Hancock Fdn., 23: $1-335$.
HARTMAN, O., 1959b, Catalogue of the Polychaetous Annelids of the World. Pt. II. Occ. Pap. Allan Hancock Fdn., 23: 336-628.

HARTMAN, O., 1963a, Submarine canyons of Southern California. Part II. Biology. Allan Hancock Pacific Exped., 27: $1-424$.

HARTMAN, O., 1963b, Submarine canyons of Southern California. Part III. Systematics: Polychaeta. Allan Hancock Pacific Exped., 27: 1-93.

HARTMAN, O., 1965, Catalogue of the Polychaetous Annelids of the World. Supl. Allan Hancock Found. Publ. occ. paper, 23: 1-197.

HARTMAN, O., 1968, Atlas of the Errantiate Polychaetous Annelids from California. Los Angeles, Allan Hancock Found. 828p.

HARTMAN, O., 1969, Atlas of the Sedentariate Polychaetous Annelids from California. Los Angeles, Allan Hancock Found. 812p.

MANGUM, C. P. \& COX, C. D., 1971, Analysis of the feeding response in the onuphid polychaete Diopatra cuprea (Bosc). Biol. Bull., 140: 215-229.

MANGUM, C. P., SANTOS, S. L. \& RHODES-JR, W.R., 1968, Distribution and feeding in the onuphid polychaete, Diopatra cuprea (Bosc). Mar. Biol., 2: 33-40.

MARTIN, A. \& LOSADA, F., 1997, Habitos alimentarios del poliqueto anfinomido Hermodice carunculata (Pallas), en la Isla Larga, Estado Carabobo, Venezuela. In: CONGRESSO LATINO-AMERICANO SOBRE CIÊNCIAS DO MAR - COLACMAR, 7., 1997, Santos. Resumos expandidos. p. 140.

MATTSON, S., 1981, Burrowing and feeding of Goniada maculata Ørsted (Polychaeta). Sarsia, 66: 49-51.

MAYER, M. S., SCHAFFNER, L. \& KEMP, W. M., 1995, Nitrification potentials of benthic and burrow walls: effects of sediment $\mathrm{NH}_{4}^{+}$and animal irrigation behavior. Mar. Ecol. Prog. Ser., 121: 157-169.

METTAM, C., 1980, On the feeding habits of Aphrodita aculeata and commensal polynoids. J. mar. biol. Ass. U.K., 60: 833-834.

MYERS, A. C., 1972, Tube-worm relationships of Diopatra cuprea (Polychaeta: Onuphidae). Mar. Biol., 17: 350-356.

OCKELMANN, K. W. \& VAHL, O., 1970, On the biology of the polychaete Glycera alba, especially its burrowing and feeding. Ophelia, 8: 275-294.

PARDO, E. V., 1995, Padrões de distribuição e estrutura trófica dos poliquetos da região entremarés de praias da Ilha de São Sebastião (Ilhabela, SP). Rio Claro: UNESP. 76p. Dissertation (Master Degree in Zoology) - Universidade Estadual Paulista.

PARDO, E. V., 2000, Comportamento, dieta e grupos funcionais de alimentação de anelídeos poliquetas da região entremarés de praias arenosas do Canal de São Sebastião $(S P)$. Rio Claro: UNESP. 74p. Thesis (PhD Degree in Zoology) - Universidade Estadual Paulista.

PECKOL, P. \& BAXTER, D., 1986, Population dynamics of the Onuphid polychaete Diopatra cuprea (Bosc) along a tidal exposure gradient. Est. Coast. Shelf. Sci., 22: 371-378. 
PETTIBONE, M. H., 1982, Annelida. pp. 1-43. In: Synopsis and Classification of Living Organisms. McGraw-Hill, Inc. - Parker, S. P. ed., New York.

PLEIJEL, F., 1983, On feeding of Pholoe minuta (Fabricius, 1780) (Polychaeta: Sigalionidae). Sarsia, 68: 21-23.

SCAPS, P., 1995, Intraspecific agonistic behavior in the polychaete Perinereis cultrifera (Grübe). Vie Milieu, 45: 123-128.

SHAFFER, P. L., 1979, The feeding biology of Podarke pugettensis (Polychaeta: Hesionidae). Biol. Bull., 156: 343355.

STEINER, T. M. \& AMARAL, A. C. Z., 2000, Two new species of Marphysa Quatrefages, 1865 (Eunicidae, Polychaeta) from intertidal sandy beaches of the São Sebastião Channel, State of São Paulo (Brazil). Bull. Mar. Sci., 67: 479- 489.

SUADICANI, S. O. \& MOREIRA, M. G. B. S., 1988, Aspectos comportamentais do poliqueto Eurythoe complanata
(Amphinomidae). In: REUNIÃO ANUAL DA S.B.P.C., 40., 1988, São Paulo, USP. Resumos Ciência e Cultura, Suppl., São Paulo, 40: 992-993.

SUADICANI, S. O., FREITAS, J. C. \& SAWAYA, M. I., 1993, Pharmacological evidence for the presence of a betaadrenoceptor-like agonist in the amphinomid polychaete Eurythoe complanata. Comp. Biochem. Physiol., 104C: 327-332.

UEBELACKER, J. M. \& JOHNSON, P. J., 1984, Taxonomic guide to the polychaetes of the Northern Gulf of Mexico. Mobile, Alabama: Barry A. Vittor \& Associates, Inc. 7 vols.

VREELAND, H. V. \& LASKER, H. R., 1989, Selective feeding of the polychaete Hermodice carunculata Pallas on Caribbean gorgonians. J. Exp. Mar. Biol. Ecol., 129: 265277. 